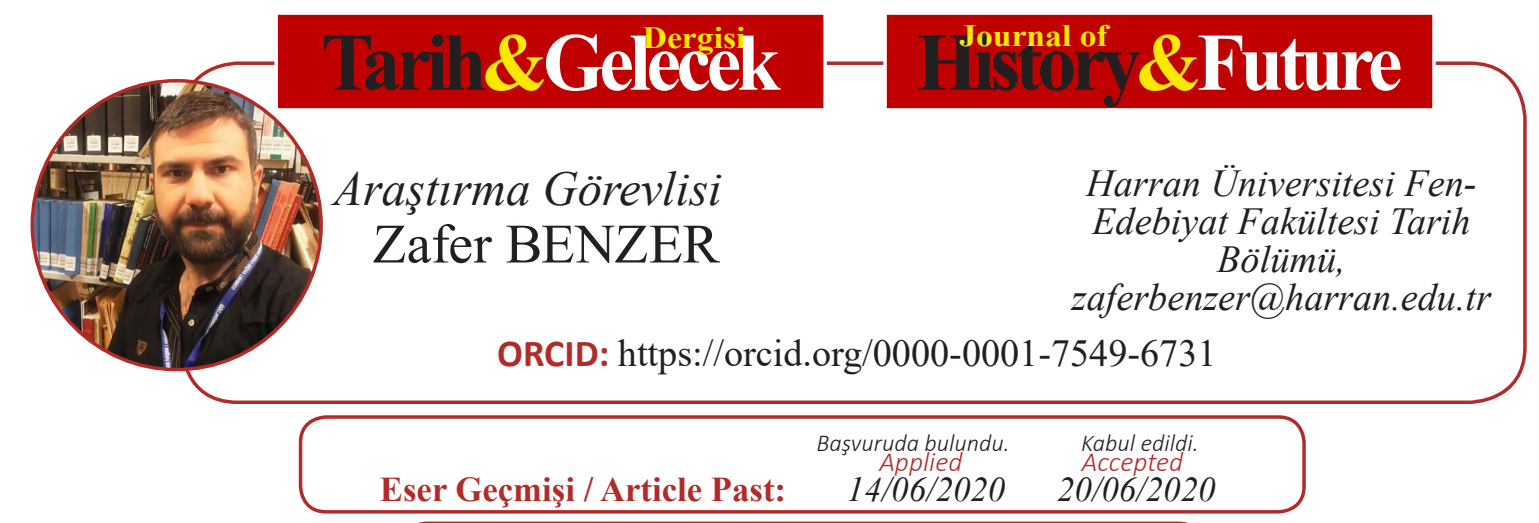

Araștırma Makalesi

DOI: http://dx.doi.org/10.21551/jhf.753522

Research Paper

Orjinal Makale / Orginal Paper

\title{
Urfa Tereke Kayıtlarına Bir Örnek: Göncü Hacı Abdurrahman'1n 1880 Tarihli Terekesi
}

An Example Of Urfa Tereke Register: Leather Dealer Hadji Abdurrahman's Tereke Dated 1880

\section{$\ddot{O} z$}

Osmanlı Devleti tarihi kaynakları arasında kadıların kaleme aldıkları Şer ‘iye Sicilleri önemli bir yere sahiptir. Kadı defterleri de denilen bu sicillerde yer alan ve önem arz eden bir belge türü ise tereke kayıtlarıdır. Ölen kimsenin miras olarak bıraktılarına "tereke", Arapçada "terike" veya "tirke" denir. Şer’iye Sicilleri içinde, ölen kimselerin vârislerine biraktıkları menkul ve gayr-ı menkulleri içeren tereke kayıtları, sosyal ve iktisadi tarih bakımından zengin bilgiler içermektedir. Nitekim aile yapısını, ailenin sosyal, kültürel ve iktisadi durumunu tereke kayıtlarından yaklaşık olarak çıkarmak mümkündür. Bu çalışmada, Urfa'da yaşamış olan ve varlıklı bir kişi olarak kabûl edebileceğimiz Göncü Hacı Abdurrahman'ın H. 3 Şa bân 1297/M. 11 Temmuz 1880 tarihli tereke kaydı esas alınmış, Hacı Abdurrahman ve ailesini ilgilendiren diğer belgeler incelenmiştir. Tek eşliliğin hâkim olduğu Osmanlı aile yapısının aksine üç evlilik yapmış olan Abdurrahman'ın mirası ve bu mirasın paylaşımı kadı mahkemesine intikal etmiştir. Genelde Osmanlı ve özelde Urfa toplumunda çok eşliliğe örnek teşkil eden bu kayıt, ölen kişinin mirasının ve mirasçılarının belirlenme usulü, mirasın taksim şekli gibi konularda önemli bilgiler içermektedir. Bu bilgiler ışığında, ölen şahsın tereke kayıtları esas alınarak Urfalı bir ailenin evi, sosyal hayatı ve iktisâdı hakkında bilgiler verilmiştir.

Anahtar kelimeler: Şer ‘iye Sicilleri, Tereke, Miras, Urfa, Göncü Hacı Abdurrahman.

* Bu çalışma, GAP Zirvesi kapsamında 4-6 Mayıs 2018 tarihleri arasında Şanlıurfa'da düzenlenen II. Uluslararası Piri Reis Dil-Tarih-Coğrafya Kongresi’nde sözlü olarak sunulmuş ve özet olarak basılmıştır. 


\section{Abstract}

Among the resources of the Ottoman State history, Şer'iye Registries written by kadi (Muslim judges) have a significant place. One type of the documents involved and has importance in these registries that is also called kadi records is tereke registries. What is left from the deceased as an inheritance is called "tereke", and in Arabic "terike" or "tirke". Tereke registries of şer'iye records that include moveable and real estate properties left to the inheritors by the deceased involve rich information about the social and economic history. Thus, it is possible to reveal the family structure and the social, cultural, and economic conditions of the family roughly according to the tereke registries. This study is based on the tereke registry dated H. Shaban 3, 1297/ M. July 11, 1880 of the leather dealer Hadji Abdurrahman who lived in Urfa and can be considered as a wealthy man and also other documents concerning Hadji Abdurrahman and his family were examined. The inheritance of Abdurrahman who was married three times in contrast to the Ottoman family structure where monogamy was predominant and the portion of the inheritance were taken to the kadi court. This registry that sets an example of polygamy generally in the Ottoman and specifically in Urfa society involves significant information on the issues such as the procedure how the inheritance and inheritors of the deceased were determined and how the inheritance was shared. In the light of this information, home of a family in Urfa and their social life and finances were reported based on the tereke registries of the deceased.

Key words: Şer'iye Registries, Tereke, Inheritance, Urfa, Leather Dealer Hadji Abdurrahman.

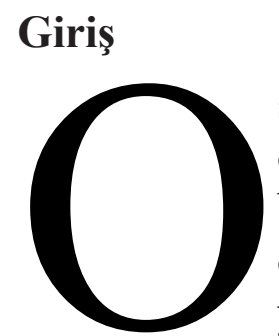

smanlı Tarihi ve kültürü hakkında yapılacak araştırmalar için gerekli olan kaynakların başında arşiv belgeleri gelmektedir. Tarihimizin sahih bilgileri arşiv belgelerinde saklıdır. Belgesiz tarih yazılamayacağı gibi olayların gerçek yönleri de gün 1şığına çıkarılamaz. Arşiv belgeleri yalnızca geçmişin siyasi hadiselerine değil, döneminin her türlü sosyal, kültürel ve ekonomik olaylarına da 1şı tutar. Özellikle yerel tarih için en önemli kaynaklardan biri olan Şer'iye Sicil Defterleri, bugünkü anlamıyla Osmanlı dönemindeki şerî mahkeme kayıtlarıdır. Kadı sicilleri, kadı divanı, mahkeme kayıtları, sicillât-ı şer‘iyye ve yaygın kullanımı ile șer'iye sicilleri denilen bu defterler kadı yahut nâibi tarafından tutulmakta ve çeşitli türden belgeleri içermektedir. Osmanlı Devleti'nde merkezde ve taşrada her tabakadan insanlar arasındaki hukukî ilişkilere dair kayıtları içeren bu defterler Osmanlı hayatının aile, toplum, ekonomi ve hukuk gibi birçok alanının tarihi için en önemli kaynaklardır .

$1 \quad$ Kadı sicillerinin kaynak olarak arz ettikleri önem hakkında bkz. Ahmet Akgündüz, Şer'iyye Sicilleri Mahiyeti Toplu Kataloğu ve Seçme Hükümler I, 1. Baskı, (İstanbul: TDV Yayınları, 1988); Ahmet Akgündüz, "İslam Hukukunun Osmanlı Devleti’nde Tatbiki: Şer'iyye Mahkemeleri ve Şer'iyye Sicilleri”, İslam Hukuku Araştırmaları Dergisi, 14, (2009); Yunus U̧ğur, "Şer"iyye Sicilleri”, TDV Islam Ansiklopedisi, c. 39, (2010): 8; Abdülaziz Bayındır, “Osmanlı’da Yargının İşleyişis”, Osmanlı, c. 6, (1999): 432. 
Sicillerde mevcut olan yazılı kayıtları iki kısma ayırabiliriz. Birincisi, kadılar tarafından inşa edilerek yazılan kayıtlardır ki sicillerdeki kayıtların büyük bir çoğunluğunu bu tür belgeler oluşturmaktadır. İkincisi ise bizzat kadıların ortaya çıkardığı belgeler değil de dışarıdan gelerek sicile kaydedilen belgelerdir. Çünkü kadılar şerî işlerin yanı sıra bulundukları bölgede yürütme gücünü de ele almışlardır. Bu yüzden taşraya gönderilen fermanların büyük çoğunluğu kadılara hitaben yazılırdı ${ }^{\Upsilon}$. Kadıların kaleme aldıkları şer'iye sicil kayıtları arasında hüccet, i'lâm, ma'ruz, mürâsele, mektup, ferman, berat, buyruldu, tezkire, temessük, vakfiye gibi çeşitli konularda belgeler bulunmaktadır³.

Kadı defterlerinde yer alan ve önem arz eden bir başka belge türü ise tereke kayıtlarıdır. Ölen kimsenin mirâs olarak bıraktıklarına "tereke" Arapçada "terike" veya "tirke" denir". $\mathrm{Bu}$ kelimelerin yerine belgelerde sözlükte "geride bırakılan, geriye kalan" anlamlarına gelen muhallefin çoğulu olan "muhallefât" kelimesi de kullanılmaktadır". Bırakılan şeyler, miraslar anlamında da "metrûkât" ifadesini görmekteyiz ${ }^{6}$. Kişilerin ölümlerinden sonra varislerine bıraktığı mirası içeren tereke kayıtları, ekonomik ve sosyal tarihimiz için kıymetli belgelerdir. Bu kayıtlardan ölen şahsın iktisadi durumu, sahip olduğu mal varlığı, bu malın maddi değeri, alacak verecek ilişkileri, aile üyeleri, mirasın nasıl taksim edildiği, şehrin mutfak özellikleri, giyim kuşam ve eş eşyası, konfor veya lüksün seviyesi gibi pek çok konuyu ayrıntılı bir şekilde öğrenmek mümkündür ${ }^{7}$. Bu özellikleri bakımından tereke kayıtları, hukuk ve sosyal-kültürel tarihimiz bakımından da büyük kıymeti haizdirler. Osmanlı Devleti tarihinin gerektiği gibi aydınlatılmasına her yönüyle 1şık tutan arşiv kayıtları arasında yer alan tereke defterleri, yerel tarih ve iktisat tarihi gibi alanlarda da önemli bilgiler içermektedir. Dolayısıyla geçmişten günümüze değin bizzat tereke kayıtları esas alınarak veya dolaylı olarak bu kayıtlardan faydalanma yoluyla çok sayıda değerli çalışma yapılmıştır ve yapılmaya devam edilmektedir8.

Normal şartlarda terekeler sicil defterlerine temel olarak üç veya dört bölüm halinde kaydedilmektedir. İlk bölümde tereke kaydının özelliklerine göre bir giriş cümlesinden sonra vefat eden kişinin adı, icra ettiği mesleği, varsa unvanı veya lakabı, nerede ve ne

2 Ali Aktan, Osmanlı Paleografyası ve Siyasi Yazı̧̧malar, (İstanbul: İlim ve İrfan Vakfı Yayınları, 1995), 117.

3 Muhammed Ceyhan, "Tanzimat Dönemi Sonrası Şer'iyye Sicil Defterlerinin Muhteva ve Diplomatik Açıdan Tahlili", OTAM, 29, (2011): 55.

4 Hamza Aktan, "Miras", TDV İslam Ansiklopedisi, c. 30, (2005): 144.

5 Tahsin Özcan, "Muhallefât", TDV İslam Ansiklopedisi, c. 30, (2005): 406.

6 Ferit Devellioğlu, Osmanlıca-Türkçe Ansiklopedik Lügat, 14. Baskı, (Ankara: Aydın Kitabevi Yayınları, 1997), 633.

7 Ömer Lütfi Barkan, “Edirne Askeri Kassamı'na Ait Tereke Defterleri (1545-1659)”, Belgeler, III/5-6, (1996): 1-2.

8 Bu alanda yapılan çalışmaların tümünden burada bahsetmek mümkün olmamakla birlikte bazıları şunlardır: Barkan, "Edirne Askeri Kassamı'na Ait Tereke Defterleri (1545-1659)", Belgeler, III, 5-6, (1996): 1-479; Said Öztürk, Askeri Kassama Ait Onyedinci Asır İstanbul Tereke Defterleri, (İstanbul: OSAV Yayınlar1, 1995); Said Öztürk, "Tereke Defterlerine Göre XVII. Asırda İstanbul'da Aile Nüfusu, Servet Yapısı ve Dağılımı”, İstanbul Araştırmaları, 3 (1997): 21-57; L. Fekete, "XVI.Yüzyılda Taşralı Bir Türk Efendisinin Evi”, (Çev. Sadrettin Karatay), Belleten, XXIX/115-116, (1965): 615-638; Musa Çadırcı, "Hüseyin Avni Paşa'nın Terekesi", Belgeler, XI/15, (1986):145-164; Fatih Bozkurt, "Osmanlı Dönemi Tereke Defterleri ve Tereke Çalışmaları", Türkiye Araştırmaları Literatür Dergisi, 11/22, (2013): 193-229; Nuri Köstüklü, "Osmanlı-Türk Aile Kurumu Araştırmalarında Tereke Defterlerinin Yeri ve Önemi (19. YY. Örnekleri Çerçevesinde)", Uşak Üniversitesi Sosyal Bilimler Dergisi, 1/1, (2008): 17-26. 
zaman vefat ettiği, varsa vârisleri ve bunların miras paylaşımları gibi bilgiler verilir. İkinci bölümde, ölen kişinin geride bırakmış olduğu taşınır veya taşınmaz mallarının listesi ve bunların fiyatları bulunmaktadır. Üçüncü bölümde ise listedeki malların toplam değeri hesaplanarak, bu miktardan ölen kişinin cenaze giderleri, mahkeme harç ve masrafları, vasiyetleri düşülerek mirastan kalan meblağ deftere kaydedilmektedir ${ }^{9}$. Dördüncü ve son bölümde de bu kayıttan sonra mirasın mirasçılar arasında pay edilmesi ve paylarına düşen hissenin değeri belirtilmektedir ${ }^{10}$. İncelememize esas olan tereke kaydının da dört bölümden oluştuğu söylenebilir. Ayrıca bu kayıtta istisna olarak üç tereke kaydı aynı belge numarasıyla verilmiştir. Çünkü ölen üç kişi birbirinin varisi durumundadır. Tereke kaydının birinci bölümünde ölenin kimliği, vârisleri, belgenin tarihi yer alırken; ikinci bölümünde mûrisin mal varlığı, üçüncü bölümde harcamalar ve varsa borcu, dördüncü ve son bölümde ise vârislerin isabet eden hisseleri belirtilmiştir.

\section{Göncü Hacı Abdurrahman'ın Hayatı Üzerine Bazı Tespitler}

Bahsimize konu olan Abdurrahman, Sakacı Osman'ın, Osman ise Abdullah'ın oğludur. Belgelerde Göncü Hacı Abdurrahman b. Sakacı Osman b. Abdullah şeklinde zikredilmektedir. Ailesi Urfa'nın varlıklı ailelerinden biridir. Babası Osman, lakabından anlaşıldığına göre "sakacı" esnafına mensuptu. Bu meslek, evlere para karşılığında su taşıma işini gerçekleştirirdi ${ }^{11}$. Bu tabir Osmanlı Devleti'nde Yeniçeri Ocağı'nın su ihtiyacını karşılayan grup için kullanılmıştır. Kelimenin kökeni, Arapça "sakka"dan gelmektedir. Devlet bünyesinde köklü ıslahatların yapıldığı, yeniliklerin baş gösterdiği II. Mahmut döneminde Yeniçeri Ocağı'nın kaldırılması öncesinde saka adı "sebilci" olarak değiştirilmiştir. Saka teşkilatı sarayda da bulunurdu ve yöneticilerine "sakabaşı" denilmekteydi. Bu tabir aynı anlamda halk arasında da kullanılmaktayd1 ${ }^{12}$.

Urfa şehri, merkezinde veya yakınında akarsular olmasına rağmen XIX. yüzyılın ikinci yarısına kadar su temini konusunda sıkıntılar yaşamıştır. Öyle ki bu tarihe kadar her evin avlusunda su ihtiyacını karşılayabilecek kuyular mevcut değildi. Su ihtiyacını dışardan karşılamak mecburiyetinde kalan ahali, şehirde su taşıma işi yapan sakalardan faydalanmaktaydı. Sakalar, hayvanlar üzerine yerleștirdikleri kovalarla Karakoyun Deresi'nden, Halilürrahman ve Aynzeliha göllerinden evlere para karşıllğında su taşırlardı. Sakacılara para ödeyemeyecek durumda olan ahali ise su ihtiyacını kendisi karşılardı. Dolayısıyla halk arasında zengin denilebilecek kimselerin sakacı esnafına başvurduğu söylenebilir ${ }^{13}$.

9 Ekrem Tak, Diplomatik Bilimi Bakımından XVI.-XVII. Yüzyıl Kadı Sicilleri ve Bu Sicillerin İhtiva Ettiği Belge Türlerinin Form Özellikleri ve Tanımlanması, Yayımlanmamış Doktora Tezi, (İstanbul: Marmara Üniversitesi Türkiyat Araştırmaları Enstitüsü, 2009), 159.

10 Özcan, "Muhallefât", 407.

11 Uğur Göktaş, "Sakalar”, Dünden Bugüne İstanbul Ansiklopedisi, c. 6, (İstanbul: Kültür Bakanlığ1 ve Tarih Vakfı Yayınları, 1994), 420.

12 M. Zeki Pakalın, Osmanlı Tarih Deyimleri ve Terimleri Sözlüğü-III, (İstanbul: Milli Eğitim Basımevi, 1983), 96.

13 Mahmut Karakaş, Urfa’nın Kültür ve Inançlar Serüveni, (Şanlıurfa: Şanlıurfa Valiliği İl Kültür ve Turizm Müdürlüğü Yayınları, 2009), 441. 
Abdurrahman'ın ise babası gibi sakacı olmadığı, "göncü” esnafına mensup olduğu görülür. 'Gön' işlenmiş hayvan derisi demektir. 'Göncü' ise ham veya işlenmiş deriyi satan kimsedir ${ }^{14}$. İsminin önüne "Göncü" lakabıyla birlikte "Hacı" unvanı da eklenmesi Hac farizasını da yerine getirmiş olduğunu göstermektedir. Urfa'nın Askeriye (Askeri) Mahallesi'nde ${ }^{15}$ ikamet eden Hacı Abdurrahman'ın üç evlilik yaptığı kayıtlardan anlaşılmaktadır. Salih ve Ahmet adlarında iki erkek, Zübeyde, Rabia ve Fatma adlarında üç kız çocuğu babasıdır. Kızları Zübeyde, annesi Hedule'den sonra, babası Hacı Abdurrahman'dan önce vefat etmiştir. Eşlerinden biri olan Hedule binti İsa b. Süleyman kendisinden önce vefat etmiştir. Diğer ikisi ise hayattadır ve terekeye kaydedilmiştir. Hedule'nin doğum tarihi ve ölüm yılı verilmemekle birlikte, terekenin deftere tutulduğu tarih itibariyle vefat tarihini öğrenebiliyoruz. Belge tarihi H. 1297/M. 1880' dir. Belgenin girişinde “...tarihinden beş sene mukaddem vefât eden..." ${ }^{16}$ şeklinde geçen ibareden anlaşlacağ Hedule, H. 1292/M. 1875 yılında vefat etmiştir denilebilir. Tereke kaydında ölüm nedeni yazmamaktadır. Ancak vârislerini ilgilendiren başka bir kayıttan anladığımız kadarıyla bir hastalığa yakalanmış ve bu hastalıktan dolayı vefat etmiştir ${ }^{17}$.

Diğer eşleri ise Hacı Münife binti Mehmet Harran ve Safiye binti Eyyub'dur. Hacı Abdurrahman'ın ilke eşi kuvvetle muhtemel Hacı Münife (Münifiye)'dirr ${ }^{18}$. Ancak kayıtlardan anlaşıldığı kadarıyla bu eşiyle çocuk sahibi değillerdir. Her ikisinin de Hacı unvanıyla anılması beraber Hac vazifesini yerine getirdiklerini düşündürmektedir. Hacı Abdurrahman'ın ilk eşi Münife'den çocuğu olmadığ iç̧in ikinci eşi Hedule ile evlendiği güçlü bir ihtimaldir. Üçüncü eşi ise ölümünden 5 sene önce yani $1875^{\prime}$ te evlendiği anlaşılan Safiye binti Eyyub'dur ${ }^{19}$ ve ondan Ahmet isimli bir oğlu vardır. Dolayısıyla Hedule'nin ölümünden hemen sonra Safiye ile evlenmiştir.

$\mathrm{Bu}$ örnekten de anlaşılacağı üzere Osmanlı aile yapısında eş ve çocuk durumu hakkında bize ipucu veren önemli kaynaklardan birisi de hiç şüphesiz tereke defterleri olduğunu görmekteyiz. Tereke kayıtları tutulurken ölen kimsenin künyesi verildikten sonra

14 Türk Dil Kurumu Sözlüğ̈̈, https://sozluk.gov.tr/; Gön mesleği ve Göncü esnafı hakkında tafsilatlı bilgi için bkz. Ali Tenik, "Tasavvufi Teşkilat Ahîliğin Urfa'daki Tarihi Seyri ve Etkileri”, II. Uluslararası İslam Tarihi ve Medeniyetinde Şanlırfa: Osmanll Belge ve Kaynaklarında Urfa, c. III, (Şanlıurfa: Şanlıurfa Büyükşsehir Belediyesi, Kültür ve Sosyal İşler Müdürlüğ̈̈̈ Kültür Yayınları, 2018), 280-296; Fatma Nur Başaran, "Debbağlık-Kürkçülük-Saraçlık", Şanlıurfa El Sanatları ve Sözlü Kültür Malzemeleri, (2012): 447-449 (447-458).

15 BOA, MŞH.ŞSC.d., Urfa Şer'iye Sicili, Sicil No: 208, Sayfa No: 116, Belge No: 734. Buradan sonraki atıflarda USSS., 208, 116/734 şeklinde kısaltılarak verilecektir. Bu defter yüksek lisans tezi olarak çalışılmıştır. Bkz. Mehmet, Şilen, 208 Numaralı Urfa Şeriyye Sicili Transkripsiyon ve Değerlendirilmesi (H.1296-1299/M.1879-1882), Yayımlanmamış Yüksek Lisans Tezi, Harran Üniversitesi Sosyal Bilimler Enstitüsü, Şanlıurfa, 2015.

16 UŞS., 208, 149/814.

17 “...kebîre-i mezbûre Râbi’a ile ve sağîre-i mezbûre Fatma’nın vâlideleri Hedule vefât edip lakin vefâtından bir buçuk sene akdemi mütecâviz maraz-1 müzmîne-ye müptelâ..” UŞS., 208, 116/733.

1818 Mayıs 1880 tarihli kayıtta, Hacı Münife vekili Hacı Şaban Ağa b. Mehmed aracılı̆̆ıyla eși Abdurrahman'ın terekesinden talep ettiği mihr-i muahharı ve 5 kile hıntasını talep ederken "..yirmi yedi sene mukaddem müvekkilem mezbureyi nefsine akd ve tecvizde..” şeklinde geçen ifade dikkat çekmektedir. Dolayısıyla bu bilgiye dayanarak Hacı Abdurrahman ve Hacı Münife'nin 1853 'te evlendikleri söylenebilir. UŞS., 208, $137 / 780$.

1915 Mayıs 1880 tarihli kayıtta, Safiye binti Eyyub'un vekili İmam b. Eyyub'un “..Hacı Abdurrahman'ın b. Sakacı Osman b. Abdullah tarihinden beş sene mukaddem müvekkilemi nikahına akd ve tezvicinde.." şeklinde bir ifade kullanıldığ görülmektedir. UŞS., 208, 121-122/745. 
vâris olarak eşi veya eşlerinin isimleri zikredilmektedir. $\mathrm{Bu}$ da bize kişinin kaç evlilik yaptığını öğrenmek açısından bilgi vermektedir ${ }^{20}$. Dolayısıyla tereke defterleri Osmanlı toplumunun demografik özelliklerini yansıtması açısından önemlidir. Kişinin ölümü sonrasında tutulan bu kayıtlarda ailesine kalan mirasının belirlenmesi ve İslam hukukuna göre pay edilmesi amaçlanmaktadır. Ölüm nedeniyle ortaya çıkan bu kayıtlar vasıtasıyla, Osmanlı toplumunda meydana gelen ölümlerin aylık, yıllık ve mevsimsel dağılımı hakkında bilgi edinilebilmektedir. Öte yandan tereke kayıtlarında ölen kişinin mirasçılarının tek tek belirtilmesi suretiyle, ailenin sahip olduğu çocuk sayısı, eş sayısı ve mirasçıların akrabalık ilişkileri gibi hususlarda da güvenilir bilgiler elde etmek mümkün olmaktadır ${ }^{21}$.

11 Nisan 1880 tarihli kayda göre, Göncü Hacı Abdurrahman kendisi gibi göncü esnafından olan kardeşi Hacı Mamo ve onun eşi Aynzeliha binti Mehmet'in ölümü üzerine kimsesiz kalan küçük oğulları Mehmet Bakır'a vâsilik yapmıştır. Hacı Abdurrahman ölümü üzerine Mehmet Bakır'ın kız kardeşi Rabia'nın kocası ve şer'an vâsisi olan İmam Hüseyin b. İri Sülo22 mahkemeye başvurarak, Mehmet Bakır'a babasından kalan 3.000 kuruş ve annesinden kalan 1.500 kuruşun önceki vâsisi Abdurrahman'ın elinde olduğunu söylemiştir. Abdurrahman'1n 500 kuruşu daha sağ iken Mehmet Bakır'ın annesine verdiğini, kalan 4.000 kuruşun ise Abdurrahman'ın vâsiy-i muhtarı Halil b. İsa'dan talep ettiğini ve bunun da Abdurrahman'ın terekesinden tahsil edilmesini istemiștir' ${ }^{23}$. Göncü Hac1 Abdurrahman'ın ölüm tarihi belgelerde kesin olarak zikredilmemekle birlikte, tereke ile ilgili kayıtlarda geçen bazı ibarelerden onun 1880 yılı içerisinde vefat ettiği tahmin edilmektedir ${ }^{24}$.

\section{Göncü Hacı Abdurrahman'ın Terekesi ve Terekenin Taksimi}

İncelediğimiz sicil kaydında ilk tereke Hacı Abdurrahman'ın eşi Hedule binti İsa bin Süleyman'a aittir ${ }^{25}$. Hacı Abdurrahman'dan önce vefat eden Hedule, geride 400 kuruş değerinde 3 kat yatak ile 1000 kuruş kıymetli mihr-i müeccel bırakmıştır. 38 kuruşluk bir giderden sonra kalan 1362 kuruş varisleri arasında şu şekilde taksim edilmiştir:

Tablo 1: Göncü Hacı Abdurrahman'ın eşi Hedule'nin Tereke Kaydı

\begin{tabular}{|l|l|l|}
\hline Varisin Yakınlı̆̆1 & Ad1 & Ald1 ğ1 Hisse \\
\hline Eşi & Hac1 Abdurrahman & 342 kuruş \\
\hline Büyük k1z1 & Rabia & 205,8 kuruş \\
\hline Küçük kızı & Fatma & 205,8 kuruş \\
\hline
\end{tabular}

20 Köstüklü, "Osmanl1-Türk Aile Kurumu Araştırmalarında Tereke Defterlerinin Yeri ve Önemi (19. YY. Örnekleri Çerçevesinde)" 20.

21 Fatih Bozkurt, "Tereke Defterleri ve Osmanlı Demografi Araştırmaları", Tarih Dergisi, 54, (2012): 97. (91-120).

22 UŞS., 208, 122/747.

23 UŞS., 208, 173/861.

2411 Nisan 1880 tarihli kayıtta “....bundan üç mâh mukaddem vefat eden Göncü Hacı Abdurrahman bin Sakacı Osman bin Abdullah'ın...” USSS., 208, 173/861 cümlesinden onun Ocak ayında ya da 3 Mayıs 1880 tarihli kayıtta “...tarihinden bir mâh mukaddem vefat eden göncü esnafindan Hacı Abdurrahman bin Sakacı Osman bin Abdullah'ın...” UŞS., 208, 114/724 ifadesinden ise Nisan ayında vefat ettiği söylenebilir. 


\begin{tabular}{|l|l|l|}
\hline Küçük k1zı & Zübeyde & 205,8 kuruş \\
\hline Küçük oğlu & Salih & 410,16 kuruş \\
\hline & Toplam & 1369 kuruş $^{1}$ \\
\hline
\end{tabular}

Diğer kayıt, annesi Hedule'den sonra, babası Hacı Abdurrahman'dan önce vefat eden küçük kızları Zübeyde'ye ait olan terekedir ${ }^{26}$. Zübeyde'nin doğal olarak tek mal varlığ annesinden kalan 205,8 kuruşluk hissedir. Tek vârisi ise babası Hacı Abdurrahman'dır. Son kayıt ise Hac1 Abdurrahman'a ait olan ve yüklü bir meblağ tutan kayıttır ${ }^{27}$. Hacı Abdurrahman'in altı vârisi vardır. Zevceleri Safiye bint Eyyub ile Hacı Münifiyye bint Mehmed Harran, büyük kızı Rabia ve küçük çocukları Salih, Ahmed ve Fatma'dır. İlk kayıtlardan anlaşıldığına göre Salih, Rabia ve Fatma kendisinden önce vefat eden eşi Hedule'nin çocuklarıdır. Küçük oğlu Ahmed ise eşi Safiye binti Eyyub'dan mütevellittir ${ }^{28}$. Hac1 Abdurrahman'ın mirası 48 sehemden (hisseden) oluşmaktadır. Bu hisselerden 3'ü eşi Hacı Münife'ye, 3'ü diğer eşi Safiye'ye, 7'si büyük kızı Rabia'ya, 7'si küçük kızı Fatma'ya, 14'er olmak üzere 28'i de küçük oğulları Salih ve Ahmet'e aittir ${ }^{29}$. Hacı Abdurrahman'ın vâsiy-i muhtarı ve aynı zamanda reşit olmayan Fatma, Salih ve Ahmet'in vâsisi Halil b. İsa'dır. Safiye binti Eyyub'un vekili ve aynı zamanda kardeşi olan İmam b. Eyyub, Hacı Münife'nin vekili Hacı Şaban Ağa, Rabia'nın vekili ise Ali Bey b. Mahoş'tur ${ }^{30}$.

Merhum Hacı Abdurrahman'ın vârislerine bıraktığı menkul ve gayrı menkullerin neler olduğu aşağıda tablo halinde gösterilmiştir. Bu değerlerin bugün meblağ olarak ne miktara tekabül ettiğini tespit etmek oldukça zordur. Ancak listedeki menkul ve gayr-1 menkullerin değerleri birbiriyle mukayese edilerek sonuca gidilebilir. Daha başka terekeler incelenip terekeler arası mukayeseler yapıldığı takdirde etraflı değerlendirmelere ulaşmak mümkündür.

Mutfak eşyaları için abartılı denilebilecek bir şey bulunamamıştır. Ancak "kuzu kazanı" ile “köfte leğeni”nin bulunması Hacı Abdurrahman'ın mutfağında çiğköftenin sık yapıldığını ve kuzu kavurmanın da Urfa yemek kültürü arasında bulunduğunu göstermektedir. Günlük eşyaların yanı sıra 2 adet bakır kahve ibriği, kahve değirmeni ile tavasının bulunması da "mırra" geleneğini işaret etmektedir. Dikkati çeken diğer bir mutfak eşyası 9 adet yeşil küpün varlığıdır. Bu yeşil küpler son dönemlere kadar sarmalık üzüm yaprağı ve çeşitli salamura ve turşuların basılmasında kullanılıyordu. Son olarak Hacı Abdurrahman'ın mutfağında mangalın bulunması yöresel Urfa kültüründe önemli bir yere sahip olan ciğer kebabı ile et kebabına işaret etmektedir.

26 UŞS., 208, 150/814.

27 Göncü Hacı Abdurrahman'a ait iki adet tereke kaydı vardır. Biri 814 belge numarası ile diğeri ise 943 belge numarası ile kaydedilmiştir. 814 numaralı belgede adı geçen şahsın tüm malları, alacakları ve borçları yer alırken, 943 numaralı belgede ise tohum ortaklarından alacağ 1 tutar esas alınarak yapılan taksim ele alınmıştır. Biz bu çalışmada bu iki terekeyi beraber değerlendireceğiz. UŞS., 208, 150-151/814; UŞS., 208, 209/943.

28 “..merkûm Hacı Abdurrahman menzil-i mezbûru merkûm Halil’e vasiyet etmezden mukaddem her ne kadar iş bu menzili senin nefsine vasiyet ediyor olsam da zâhirî batnına muhâlif benim vefâtımdan sonra menzil-i mezbûrdan zevcem Safiye'den mütevellid sulb-i sağîr oğlum Ahmed ile Safiye'ye hisse verilmeyip.." UŞS., 208, 152/817.

29 UŞS., 208, 114/724.

30 UŞS., 208, 136/779. 
Hacı Abdurrahman'ın terekesinde aydınlatma aracı olarak bir lamba, bir şamdan ve bir fânus bulunuyordu. Urfa'da petrol lambası ile aydınlatma usulünü henüz pek kimse bilmiyordu. Gece karanlığı iç yağlarla yapılmış mumlarla aydınlatılırdı. Taşımak için bezden yapılan fenerler ve susam yağ yakılan kandil kullananlar da vard1 ${ }^{31}$. Bu da Hacı Abdurrahman'ın zenginliğini göz önüne getirdiğinizde aşırı bir lüksün olmadığını göstermektedir.

Terekede yatak olarak bir kat köhne yatak olduğunu görüyoruz. Bu zenginliğe rağmen tek kat yatakla idare edildiğini düşünmek imkânsızdır. Hacı Abdurrahman'ın kendinden önce vefat eden eşi Hedule'nin terekesinde üç kat yatak olduğunu görmüştük. Kat olarak yazıldı̆̆ından döşek, yorgan ve yastıkların tek kalemde yazıldığını belirtmekte fayda vardır. Çeyiz kültürünün binlerce yıllık varlığını göz önüne getirdiğimizde diğer eşleri Safiye ile Hacı Münife'nin de en az üçer kat yatağı olduğunu söyleyebiliriz. Bunların dışında sekizi yapağı yastık olmak üzere 14 adet yastık vardı. Hacı Abdurrahman'ın evinde tennur kürsüsü ile tennur yorganı adıyla iki kalem tereke görmekteyiz. Muhtemeldir ki kış aylarında ev halkı tandırın çevresine toplanarak ısınıyordu. Isınmayla ilgili başka bir kayıt bulmadığımızdan bu yargıya varmakta bir beis görmedik. Oturma eşyası olarak altı adet mak'ad, üç halı, altı keçe, üç kilim, üç de Halep hasırı vardı. Ev eşyaları arasında iki adet taht ve tahtaları dikkati çekmektedir. Yaz başlangıcıyla taht adı verilen ve üç ila dört yatak sığacak genişlikte, yerden yüksekliği 1-1,5 metre olan tahta veya demirden çardaklar kullanılmıştır. Yaz aylarında köylerimizde halen ya dama çıkılarak ya da bu çeşit tahtlar kullanılarak dışarıda, açık havada yatma geleneği devam ettirilmektedir.

Hacı Abdurrahman, beline abanî kuşak sarıyor, üstüne abasını giyiyor ve başına da kefiyesini sarıyordu. Bununla beraber Hacı Abdurrahman'ın bir kürkü, bir şalvarı, yaşmağı, fesi ve uyurken kullandığı çitâri entârisi de vardı. Bunların yanında kişisel eşyalarından sayabileceğimiz bir saat ile beş adet tütün tabakası vardı. Buradan Hacı Abdurrahman'ın tütün yani sigara kullandığı sonucuna varabiliriz. Hacı Abdurrahman'in terekesinden iki çift tabanca ile bir tüfek olduğunu görüyoruz. Gölpınar, Çikran ve Minare köylerinde gayr-1 menkul ve ortaklıklarının olduğunu gördüğümüzden bu silahların herhangi bir saldırıya karşı caydırıcı bir güç olduğunu anlayabiliriz. Ayrıca muhtelif Urfa Şer'iye Sicillerinde geçen gasp ve eşkıyalık olaylarına karşı da kullanılabileceğini söyleyebiliriz.

Hacı Abdurrahman'ın yarış atı yetiştiriciliği ile uğraştığını sahip olduğu iki kısrak hissesinden anlıyoruz. Biri kır, diğeri al olan kısrakların kıymeti hayvan varlığı içinde yüklü bir meblağ tutmaktadır. Bunlardan başka binek ve yük taşımak için kullanılması muhtemel bir merkep ile doru bir beygir, 23 koyun, 20 keçi de Hac1 Abdurrahman'1n terekesi arasında yerini almıştır.

Gayrı menkul olarak Gölpınar köyünde üzüm bağı, hangi mahallede olduğu belirtilmeyen iki göz dükkân hissesi de vardır. Hacı Abdurrahman'ın kendine ait tarlası olmadığ1 anlaşılmaktadır. Buna rağmen ortaklık usulü Çikran ve Minare köylerinden arpa ve buğday ekimi yapmıştır. Dükkânlarının hangi işle uğraştığı tereke kayıtlarında belirtilmemiştir. Hacı Abdurrahman'ın Askeri Mahallesi'nde biri küçük, diğeri büyük

31 Hasan Açanal, Urfa Tarihi (M.Ö. 2000 - M.S. 1400), 1. Bask1, 17, (Ankara: ŞURKAV Yayınları, 1997), 125. 
olmak üzere iki evi vardır. Büyük olan ev sicildeki diğer kayıtlarla karşılaştırıldığında büyüklük olarak en büyüklerinden biri, meblağ olarak da en pahalılarından biri olduğu görülür. Muhtemelen donanımlı bir evdi.

142.193 kuruşluk servetin 40.000 kuruşu çeşitli kişilerden olan alacağıdır. Bu meblağ, mirasın neredeyse \%28'ini oluşturmaktadır. Tamamı Müslüman olan 23 kişi Hacı Abdurrahman'a borçludur. Bu borçlarda faiz uygulanıp uygulanmadığını söylemek mevcut kayıtlara göre mümkün değildir. En yüksek borç, 12.500 kuruşla Birecikli Ömer Derviş’e aitken, en düşük borç ise 99 kuruşla Hocanın oğlu Mustafa'dan olan alacaktır. Alacakların bir kısmı köylülerde olup genel olarak arpa, buğday cinsiyle aynî olarak tahsil edilmiştir. Diğer bir kısım alacak ise lakabından da anlaşılacağı üzere gön satışından elde edilen kazançtır.

Hacı Abdurrahman öldüğünde 30.233 kuruş verecek borcu bulunuyordu. Bu borçların içinde en büyük paya sahip olan 12.272 kuruşla Yahudi Azor, ondan hemen sonra 9.499 kuruşla Hacı İbrahim gelmektedir. En düşük borcu ise 23 kuruşluk emlâk vergisidir. Hacı Abdurrahman'ın toplam terekesi yukarıda da belirtildiği gibi 142.193 kuruş olmakla beraber bunun tamamı vârisleri arasında paylaştırılmamıștır. Kayıt ve taksimat sırasında yapılan masraf ile müteveffânın borcu düşüldükten sonra kalan 103.948 kuruştan 1/3'ü Hacı Abdurrahman tarafindan vasiyet edilmiştir. Fakat terekede bu meblağın nereye harcanacağı hakkında kayıt yoktur. Muhtemelen sicilde geçen diğer kayıtlarda olduğu gibi "vücûh-1 birr ü hayr" yolunda harcanması istenmiştir ${ }^{32}$. Bu vasiyeti dışında ölmeden önce vâsiy-i muhtarı Halil b. İsa'ya terekesinden 2.000 kuruşu idâne olarak verilmesini, buradan gelecek olan senevi gelirin de kendi mahallesinde ve ashab-1 hayrattan Köroğluzâde Haydar Ağa'nın inşa ettirdiği su sebilinin tamiri ve ihtiyaçları için kullanılmasını tembihlemiştir ${ }^{33}$. Bu kesintilerden sonra kalan 68.844 kuruş vârisleri arasında taksim edilmiştir.

Tablo 2: Göncü Hacı Abdurrahman'1n Terekesinin Taksimi

\begin{tabular}{|l|l|}
\hline Tereke Toplamı & 142.193 kuruş $^{2}$ \\
\hline Harcamalar ve Borç & 38.247 kuruş 20 para $^{3}$ \\
\hline Vasiyeti 1/3 & 35.102 kuruş \\
\hline Kalan & 68.844 kuruş $^{4}$ \\
\hline Vârisleri & Vârislere Düşen Miktar \\
\hline Küçük oğlu Ahmet & 20.236 kuruş 10 para \\
\hline Küçük oğlu Salih & 20.236 kuruş 10 para \\
\hline Büyük kıı Rabia & 10.118 kuruş 15 para \\
\hline Küçük kııı Fatma & 10.118 kuruş 15 para \\
\hline Eşi Safiye & 4.339 kuruş \\
\hline Eşi Hacı Münife & 4.339 kuruş \\
\hline
\end{tabular}

32 UŞS., 208, 124-125/752.

33 “..Göncü Hacı Abdurrahman bin Sakacı Osman bin Abdullah hayatında vefâtından beş mâh mukaddem ben bi-emri'l-llâh-i ta'âla vefât eylediğimde cemî terekem ve zimem-i nâsda olan hukûkum ahz u kabz olunup sünnet-i seniyye vechi üzere teçhîz ve tekfînim görülüp düyûn-1 müsebbetem zuhur ederse ba'de'l-edâ bâki kalan terekemin sülüsünden iki bin kuruş ifrâz olunup 'alâ vücûhü' şer'î idâneye verile ve meblağ-1 mezbûrun senevî hâsıl olan semeni mahalle-i mezbûrede bulunan ashâb-1 hayrâttan Köroğluzâde müteveffâ Haydar Ağa'nın inşâsına mütevakkıf olduğu sebîl-i câri su mecrâsının lâzım gelen mahallerini ta'mîr ve tersîmine sarf oluna diye vasiyet ve tenfîzine..” UŞS., 208, 140/788. 
Mirastan en büyük hisseyi her birine 20.236 kuruşla oğulları Ahmed ve Salih almışlardır. İkinci olarak her birine 10.118 kuruşla kızları Rabia ve Fatma, son olarak da beherine 4.339 kuruşla eşleri Safiye ve Hacı Münife gelmektedir. Bu meblağların haricinde Hacı Abdurrahman'ın ölümünden önce kızı Rabia'ya kendi rızası ile teslim ettiği 1 adet altın çiçek, 120 adet Mahmudiye gâzi, 8 adet Mahmudiye altını, 20 adet eski gâzi ve 1 adet altın dobirisi (dobra) vardır ${ }^{34}$. Hacı Abdurrahman'ın eşi Hedule ise ölümünden üç ay önce kendisine ait olan 18 adet Mahmudiye gâzi, 1 çift altın reşme, altın saçlık, altın tahta bilezik gibi ziynetleri kızları Rabia ve Fatma'ya bağışlamıştır ${ }^{35}$. Diğer eşi Safiye bu ziynetleri de terekeye dahil etmek istemiş ancak Rabia ve Fatma şahitler huzurunda bunların babaları ve anneleri tarafından kendilerine verildiğini ispat etmişlerdir. Tereke taksiminden sonra 19 Ekim 1880 tarihli kayıtta Hacı Abdurrahman'ın küçük oğlu Salih ve küçük kızı Fatma’ya babalarından kalan mallarından her birine günlük 3'er kuruş nafaka bağlanmıştı³ .

\section{Sonuç}

Tereke kayıtlarını incelediğimiz Hacı Abdurrahman'ın varlıklı biri olmasına rağmen çok da gösterişli bir hayat sürmediği anlaşılmaktadır. Mal varlığı arasında en çok dikkati çeken ateşli silahlar, iki cins at, büyük bir ev ve en önemli gelir kaynağı olan göncülük ve ortakçılık yoluyla kazandıklarıdır. Bunların yanında yükte hafif, pahada ağır bir altın ayna (340 kuruş), bir çift altın bilezik (800 kuruş) ve inci maşallah (1.200 kuruş) dikkati çeken süs eşyalarıdır. Terekesinden hiç kitap çıkmaması da onun ulum ve fünun ile pek meşgul olmadığı kanaati uyandırabilir. Kardeşi Hacı Mamo ile birlikte göncü esnafından olan Abdurrahman hayırsever bir kişiliğe sahiptir. Öyle ki mirasının üçte birini hayır işleri için bağışlamıştır. Esnaflık haricinde tarım ve hayvancılık da ilgilendiği kayıtlardan anlaşılan Hacı Abdurrahman'ın kendi tarlası olmamasına rağmen Gölpınar, Çikran, Minare ve Kantara köylerinde ortaklık usulü ile ziraat yaptığı görülmektedir. Ticaret hayatı içinde de yer alan Abdurrahman hem Müslüman hem de gayrimüslimlerle alışveriş yapmıştır. Üç defa evlendiği tespit edilen bu şahsın kızı Zübeyde ve eşi Hedule'nin henüz onun sağlığında vefat ettikleri görülür.

Ölümünden sonra mirası İslam hukukunun kaidelerine göre belirlenmiş ve varislerine taksim edilmiştir. Osmanlı Devleti topraklarının genelinde olduğu gibi Urfa'da yetimin ve öksüzün malları korunmuştur. Varislerin miras hususunda beyan ettikleri söylemlerini şahitler ile ispatlamaları istenmiş ve böylelikle haksızlı̆̆ın veya mal kaçırmanın önüne geçilmeye çalışılmıştır. Hacı Abdurrahman'ın terekesinde yer alan ev ve mutfak eşyalarından yola çıkılarak Urfa'nın yemek kültürünün zengin olduğu söylenebilir. Alışverişin genelde kuruş üzerinden hesaplandığı, ancak bunun haricinde Mahmudiye altını, eski gâzi, altın dobra, Osmanî altını gibi mali birimlerin de kullanıldığı anlaşılmıştır. Bu gibi örneklerden de anlaşılacağı üzere Osmanlı Devleti döneminde tutulan tereke kayıtları sosyal ve kültürel tarih araştırmalarında önem arz etmektedir. Demografi ve yerel tarih çalışmalarında da kıymetli bilgiler içerdikleri aşikardır. Tek bir şahsın terekesinden yola çıkılarak dar bir alanda yaptığımız bu çalışmanın bir nebze de olsa faydalı olacağını ümit ediyoruz. Urfa bölgesi ile

$\begin{array}{ll}34 & \text { UŞS., 208, 118/736. } \\ 35 & \text { UŞS., 208, 116-117/733. } \\ 36 & \text { UŞS., 208, 208/941. }\end{array}$


ilgili bu alanda yapılmış ve yapılacak olan bu gibi çalışmalarla birlikte değerlendirildiğinde elde edilen bilgilerin daha sahih ve güvenilir olacağ 1 şüphesizdir.

Tablo 3: Göncü Hac1 Abdurrahman'1n Terekesi ${ }^{37}$

\begin{tabular}{|l|l|l|}
\hline Mutfak Eşyaları ve Aksesuarları & Adedi & Kiymeti (kuruş) \\
\hline Büyük sini & 1 & 120 \\
\hline Büyük teşt & 2 & 150 \\
\hline Büyük kazan & 1 & 120 \\
\hline Aş kazanı & 5 & 150 \\
\hline Kuzu kazanı & 1 & 60 \\
\hline Büyü bulgur kazanı & 1 & 360 \\
\hline Kebir satıl(strıl) & 1 & 50 \\
\hline Tas & 7 & 75 \\
\hline Üsküre tası ${ }^{5}$ & 9 & 40 \\
\hline Lenger & 6 & 70 \\
\hline Sahan & 12 & 90 \\
\hline Sahan kapağ1 & 14 & 130 \\
\hline Köfte leğeni-aş legeni & $1+2$ & 50 \\
\hline Tepsi & 2 & 20 \\
\hline Tava & 2 & 20 \\
\hline Süzgeç & 1 & 10 \\
\hline Mankal & 1 & 40 \\
\hline Havan & 1 & 15 \\
\hline Bakır Kahve İbriği & 2 & 15 \\
\hline Kahve değirmeni ve tava & 1 & 15 \\
\hline Yeşil küp & 9 & 80 \\
\hline Bulgur unu & 30 (kile) & 145 \\
\hline Ev Eşsaları, Aksesuarları ve Mefruşat & Adedi & Kıymeti(kurus) \\
\hline Yan halı & 2 & 290 \\
\hline Seccade halı & 2 & 145 \\
\hline Keçe & 6 & 400 \\
\hline Şamdan & 2 & 40 \\
\hline Kırmızı ve beyaz kilim & 3 & 100 \\
\hline Heybe & 2 & 15 \\
\hline Mak'ad ${ }^{6}$ & 6 & 290 \\
\hline Yastık & 5 & 120 \\
\hline Mitil yastık & 1 & 60 \\
\hline Lamba ma'a fanus & 2 & 15 \\
\hline Köşe döşeği & 1 & 10 \\
\hline Tennur kürsüsü & 1 & 7 \\
\hline & & \\
\hline
\end{tabular}

37 Terekedeki menkul ve gayrimenkuller defterdeki yazılışından farklı olarak sadeleştirilmiş ve sınıflandırılarak verilmiştir. 


\begin{tabular}{|c|c|c|}
\hline Tahta ma'a tahta & 2 & 100 \\
\hline Tennur yorgan1 & 1 & 80 \\
\hline Çıra kürsüsü & 1 & 4 \\
\hline Halep hasırı & 3 & 30 \\
\hline Yapağı yastık & 8 & 240 \\
\hline Çuval & 2 & 20 \\
\hline Kösele & 21 & 16.000 \\
\hline Zahire sandiğ 1 & 2 & 40 \\
\hline Aş çulhası & 1 & 5 \\
\hline Hacı Süleyman'da olan gön & 2 (şukka) & 410 \\
\hline Köhne yatak & 1 & 37 \\
\hline Büyük hal1 & 1 & 405 \\
\hline Muhtelif Malzemeler & & 531 \\
\hline $\begin{array}{l}\text { Giyim Kuşam Eşyaları, Aksesuarları ve } \\
\text { Ziynet Eşyaları }\end{array}$ & Adedi & Kıymeti(kuruş) \\
\hline Çitare entari & 1 & 76 \\
\hline Şalvar & 1 & 76 \\
\hline Kürk & 1 & 137 \\
\hline Abâni kuşak ve aba & 2 & 89 \\
\hline Köhne saat ve fes & 2 & 54 \\
\hline Hizma & 1 (çift) & 17 \\
\hline Altın ayna & 1 & 340 \\
\hline Altın koç & 1 & 80 \\
\hline Altın bilezik & 1 (çift) & 800 \\
\hline İnci maşallah & 1 & 1.200 \\
\hline Tütün tablası & 5 & 15 \\
\hline Ateşli Silahlar & Adedi & Kiymeti(kuruş) \\
\hline Tabanca çift & 2 & 240 \\
\hline Tüfenk & 1 & 100 \\
\hline Binek, Yük ve sair Hayvanat & Adedi & Kiymeti(kuruş) \\
\hline Merkep & 1 & 430 \\
\hline Koyun & 22 & 1.870 \\
\hline Keçi & 14 & 63 \\
\hline Koyun-Keçi & $1+6$ & 1.200 \\
\hline Doru bargir & 1 & 150 \\
\hline Nisf-1 al k1srak & 1 & 2.500 \\
\hline Nisf-1 kir kisrak & 1 & 3.700 \\
\hline Gayrimenkulleri & Adedi & Kiymeti(kuruş) \\
\hline Küçük menzil(konak) & 1 & 5.000 \\
\hline Gölpınar karyesinde bağ & 1 & 1.000 \\
\hline Dükkan & 2 bab nisf & 12.500 \\
\hline Büyük menzil(konak) & 1 & 35.000 \\
\hline
\end{tabular}




\begin{tabular}{|c|c|c|}
\hline Borçluları & Adedi & Kıymeti(kuruş) \\
\hline Satılan hınta(buğday) & 43 kile & 11.752 \\
\hline İbrahim Halil & & 1.486 \\
\hline Hocanın oğlu Mustafa & & 99 \\
\hline Hacı Süleyman & & 423 \\
\hline Aslanoğlu & & 309 \\
\hline $\begin{array}{l}\text { Çikran karyesinden Sağır Hamid ve } \\
\text { Hüseyin'den nısfiyette şa'ir }\end{array}$ & 21 kile & 310 \\
\hline $\begin{array}{l}\text { Minare karyesinden şeriki Hamid'den nısf } \\
\text { hınta hissesi }\end{array}$ & & 183 \\
\hline Çikran karyesinde Ali'den nısf hınta hissesi & & 1.057 \\
\hline Çikran karyesinde Alo'dan nısf hissesi & & 849 \\
\hline $\begin{array}{l}\text { Çikran karyesinde Hüseyin'den nısf hınta } \\
\text { hissesi }\end{array}$ & & 101 \\
\hline $\begin{array}{l}\text { Minare karyesinde Hamo'dan alacak yerine } \\
\text { alınan hinta }\end{array}$ & 3 kile - 7 semen & 200 \\
\hline $\begin{array}{l}\text { Çikran karyesinde Alo'dan alacak yerine } \\
\text { alınan hınta }\end{array}$ & 5 kile - 4 semen & 1112,20 \\
\hline $\begin{array}{l}\text { Çikran karyesinde diğer Alo'dan alınan } \\
\text { hınta }\end{array}$ & 3 Semen - 4 kile & 887,20 \\
\hline $\begin{array}{l}\text { Çikran karyesinde Hüseyin'den alacak } \\
\text { yerine alınan hınta }\end{array}$ & 1 kile - 4 semen & 107,10 \\
\hline Minare karyesinde Esved'den alınan hınta & 4 semen -9 kile & 1.900 \\
\hline Circo'dan alınan hınta & 3 semen -6 kile & 1287,2 \\
\hline Berho el-Cuma'dan alınan hınta & 3 semen -1 kile & 275 \\
\hline Timoroğlu Timur'dan alınan hınta & 7 semen -7 kile & 1386 \\
\hline Kantara karyesinden Circo'dan alınan şair & 13 kile & 1.040 \\
\hline Haffaf Molla Mehmed & & 1825 \\
\hline Mürselzâde Hüseyin & & 475 \\
\hline Haffaf Kundıroğlu & & 625 \\
\hline Gaffar Ağazâde Mehmed & & 4.713 \\
\hline Ali bin Osman & & 790 \\
\hline Yeşil Babazâde Hoca & & 2392,20 \\
\hline Köşker ${ }^{7}$ Topal Ali & & 198 \\
\hline Birecik'te Ömer Derviş & & 12.500 \\
\hline Urfa'da olan köşkerler & & 5.500 \\
\hline Toplam & & 142.193 kuruş $^{8}$ \\
\hline Borçlar ve Masraflar & Adedi & Kıymeti(kuruş) \\
\hline Tüccar Hacı İbrahim Ağ $a^{9}$ & & 9.499 \\
\hline Yahudi Azor $^{10}$ & & 12.272 \\
\hline Zevcesi Hacı Münife'nin ilam harc1 & & 108 \\
\hline
\end{tabular}




\begin{tabular}{|l|l|l|}
\hline${\text { Zevcesi Hacı Münife'nin hıntasi }{ }^{11}}^{1}$ & 5 kile & 950 \\
\hline $\begin{array}{l}\text { Zevcesi Safiye'nin mihr-i muahhar ile } \\
\text { mihr-i muacceleden alacağ1 }{ }^{12}\end{array}$ & & 3.851 \\
\hline Hacı Mamo'nun oğlu Mehmet Bakır & & 4.000 \\
\hline Zevcesi Hacı Münife'nin mihr-i muahharı & & 750 \\
\hline Emlak vergisi & & 23 \\
\hline Arasada satılan hıntanın vergi ve hamaliyesi & & 224 \\
\hline Cedid hınta için verilen kira & & 92 \\
\hline Defter ve mahkeme harc1 & & 1.607 \\
\hline Dellâliye & & 2.044 \\
\hline Varaka bahas1 & & 100 \\
\hline Miri üzere yüz kuruştan on kuruş kesri & & 100 \\
\hline Teçhiz ve tekfin masrafi & & 5.000 \\
\hline Adet-i ağnam resmi & & 126 \\
\hline Sebil için vasiyeti & & 2.000 \\
\hline Toplam & $42.746^{13}$ \\
\hline
\end{tabular}

\section{Kaynakça}

\section{Arşiv Kaynakları}

BOA, MŞH.ŞSC.d., Urfa Şer“iye Sicili, Sicil No: 208.

\section{İnceleme-Araştırma Eserler}

Açanal, Hasan. Urfa Tarihi (M.Ö. 2000 - M.S. 1400). 1. Bask1, S. 17, Ankara: ŞURKAV Yayınları, 1997.

Akgündüz, Ahmet. 'İslam Hukukunun Osmanlı Devleti'nde Tatbiki: Şer'iyye Mahkemeleri ve Şer'iyye Sicilleri'. İslam Hukuku Araştırmaları Dergisi, 14, (2009): 1348.

. Şer’iyye Sicilleri Mahiyeti Toplu Kataloğu ve Seçme Hükümler I, 1. Baskı, İstanbul: Türkiye Diyanet Vakfı Yayınları, 1988.

Aktan, Ali. Osmanlı Paleografyası ve Siyasi Yazışmalar. İstanbul: İlim ve İrfan Vakfı Yayınlar1, 1995.

Aktan, Hamza. "Miras”. Türkiye Diyanet Vakfı İslam Ansiklopedisi, c. 30, (2005): 143-145.

Barkan, Ömer Lütfi. “Edirne Askeri Kassamı'na Ait Tereke Defterleri (1545-1659)”. Belgeler, III/5-6, (1996): 1-479. 
Başaran, Fatma Nur. "Debbağlık-Kürkçülük-Saraçlık". Şanlıurfa El Sanatları ve Sözlü Kültür Malzemeleri, (2012): 447-458.

Bayındır, Abdülaziz. "Osmanlı'da Yargının İşleyişi”. Osmanlı Ansiklopedisi, c. 6, (1999): 429-446.

Bozkurt, Fatih. "Osmanlı Dönemi Tereke Defterleri ve Tereke Çalışmaları”, Türkiye Araştırmaları Literatür Dergisi, 11/22, (2013): 193-229.

Dergisi, 54, (2012): 91-120.

"Tereke Defterleri ve Osmanlı Demografi Araştırmaları", Tarih

Ceyhan, Muhammed “Tanzimat Dönemi Sonrası Şer' iyye Sicil Defterlerinin Muhteva ve Diplomatik Açıdan Tahlili”. OTAM, 29, (2011): 49-82.

Çadırcı, Musa. "Hüseyin Avni Paşa'nın Terekesi”. Belgeler, XI/15, (1986):145-164.

Devellioğlu, Ferit. Osmanlıca-Türkçe Ansiklopedik Lügat. 14. Baskı, Ankara: Aydın Kitabevi Yayınları, 1997.

Fekete, L. "XVI.Yüzyılda Taşralı Bir Türk Efendisinin Evi”. Çev. Sadrettin Karatay, Belleten, XXIX/115-116, (1965): 615-638.

Göktaş, Uğur. “Sakalar”. Dünden Bugüne İstanbul Ansiklopedisi, c. 6, (1994): 420.

Karakaş, Mahmut. Urfa'nın Kültür ve İnançlar Serüveni. Şanlıurfa: Şanlıurfa Valiliği İl Kültür ve Turizm Müdürlüğü Yayınları, 2009.

Köstüklü, Nuri. "Osmanl1-Türk Aile Kurumu Araştırmalarında Tereke Defterlerinin Yeri ve Önemi (19. YY. Örnekleri Çerçevesinde)". Uşak Üniversitesi Sosyal Bilimler Dergisi, 1/1, (2008): 17-26.

Özcan, Tahsin. "Muhallefât". Türkiye Diyanet Vakfı İslam Ansiklopedisi, c. 30 (2005): 406-407.

Öztürk, Said. Askeri Kassama Ait Onyedinci Asır İstanbul Tereke Defterleri. İstanbul: OSAV Yayınları, 1995.

. “Tereke Defterlerine Göre XVII. Asırda İstanbul'da Aile Nüfusu, Servet Yapısı ve Dağılımı". İstanbul Araştırmaları, 3, (1997): 21-57.

Pakalın, M. Zeki. Osmanlı Tarih Deyimleri ve Terimleri Sözlüğü-III, İstanbul: Milli Eğitim Basımevi, 1983.

Şilen, Mehmet. 208 Numaralı Urfa Şeriyye Sicili Transkripsiyon ve Değerlendirilmesi (H.1296-1299/M.1879-1882). Yayımlanmamış Yüksek Lisans Tezi, Harran Üniversitesi Sosyal Bilimler Enstitüsü, Şanlıurfa, 2015.

Tak, Ekrem. Diplomatik Bilimi Bakımından XVI.-XVII. Yüzyıl Kadı Sicilleri ve Bu Sicillerin İhtiva Ettiği Belge Türlerinin Form Özellikleri ve Tanımlanması. Yayımlanmamış Doktora Tezi, Marmara Üniversitesi Türkiyat Araştırmaları Enstitüsü, İstanbul, 2009.

Tenik, Ali. "Tasavvufi Teşkilat Ahîliğin Urfa'daki Tarihi Seyri ve Etkileri”, II. 
Uluslararası İslam Tarihi ve Medeniyetinde Şanlırfa: Osmanlı Belge ve Kaynaklarında Urfa, c. III, (2018): 280-296.

Türk Dil Kurumu Sözlüğü, https://sozluk.gov.tr/

Uğur, Yunus. "Şer'iyye Sicilleri”. Türkiye Diyanet Vakfi İlam Ansiklopedisi, c. 39, (2010): 8-11.

\section{Tablolar içerisinde kullanılan dipnotlar.}

1 Kayıtta kalan bakiye 1362 kuruş olarak yazılmış ancak hisseler hesaplandığında 1369,56 kuruş çıkmıştır. Bir kalemin yanlış yazılmış olması muhtemeldir.

2814 numaralı belgede 104.485 kuruş ve 943 numaralı belgede 37.708 kuruştur.

3814 numaralı belgede 37.514 kuruş ve 943 numaralı belgede 733 kuruştur.

4814 numaralı belgede 45.012 kuruş ve 943 numaralı belgede 24.378 kuruş olmak üzere toplamda 69.390 kuruş olarak karşımıza çıkmaktadır.

5 Topraktan veya madenden yapılmış çukur çorba tası.

6 Oturulacak yer, minder, alçak sedir gibi anlamlara gelmektedir.

7 Kundurac1, yemenici, ayakkabı tamircisi demektir.

8814 ve 943 numaralı kayıtlar birlikte hesaplanmıştır. UŞS., 208, 150/814; UŞS., 208, 209/943.

9 UŞS., 208, 132/770.

10 “..tebay-1 devlet-i Osmaniye'den millet-i Museviye'den Azor veledi Nasi..." UŞS., 208, 121/744.

11 UŞS., 208, 132/771.

12 UŞS., 208, 121-122/745.

13814 ve 943 numaralı kayıtlar birlikte hesaplanmıştır. Masraflar kısmında 814 numaralı kayıtta masrafın toplamı 37.514.20 kuruş olarak yazılmıştır. Ancak belgeyi incelediğimizde toplam çıkması gereken rakam 42.013'tür. Miras paylaşımı da belgede yazan rakam üzerinden hesaplanmış ve bu rakam üzerinden taksim edilmiştir. Bundan dolayı biz de taksimdeki sayıları değiştirme gereği duymadık. Gider kaleminden bazı masraflar terekeden değil de başka yollardan karşılanmış olabilir. Aksi takdirde miras paylaşımında bu denli bir hesap hatasının görülmemiş olması pek mümkün görünmemektedir. Masrafların genel toplamı 943 numaralı kayıttaki ile birlikte 42.746'dır. 
Ek 1: Göncü Hac1 Abdurrahman'1n 814 Numaralı Tereke Kaydı

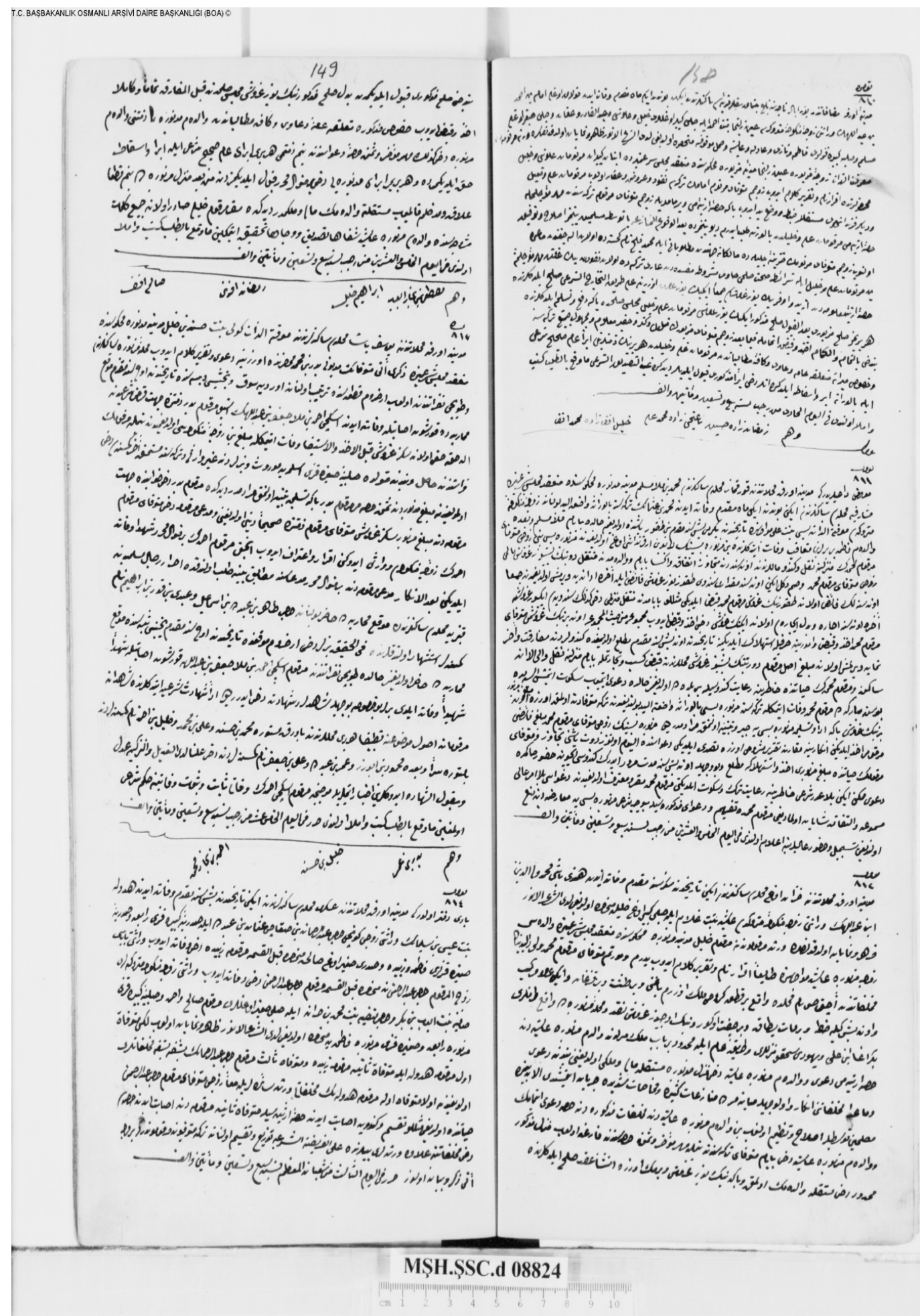

BOA, MŞH.ŞSC.d., Urfa Şer'iye Sicili, Sicil No: 208. 
Ek 2: Göncü Hacı Abdurrahman'ın 814 Numaralı Tereke Kaydı (Devamı)

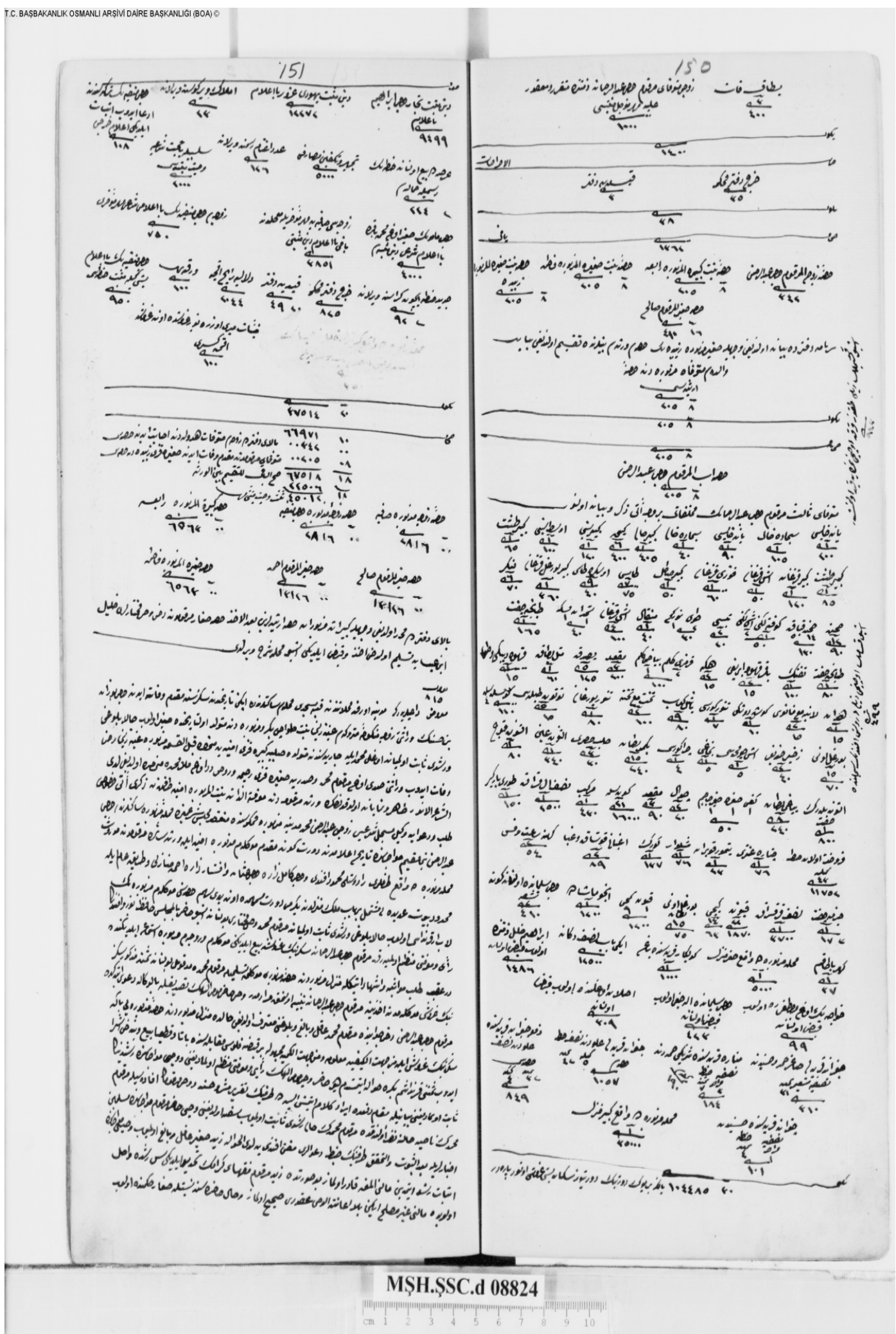

BOA, MŞH.ŞSC.d., Urfa Şer'iye Sicili, Sicil No: 208. 
Ek 3: Göncü Hacı Abdurrahman'ın 943 Numaralı Tereke Kaydı

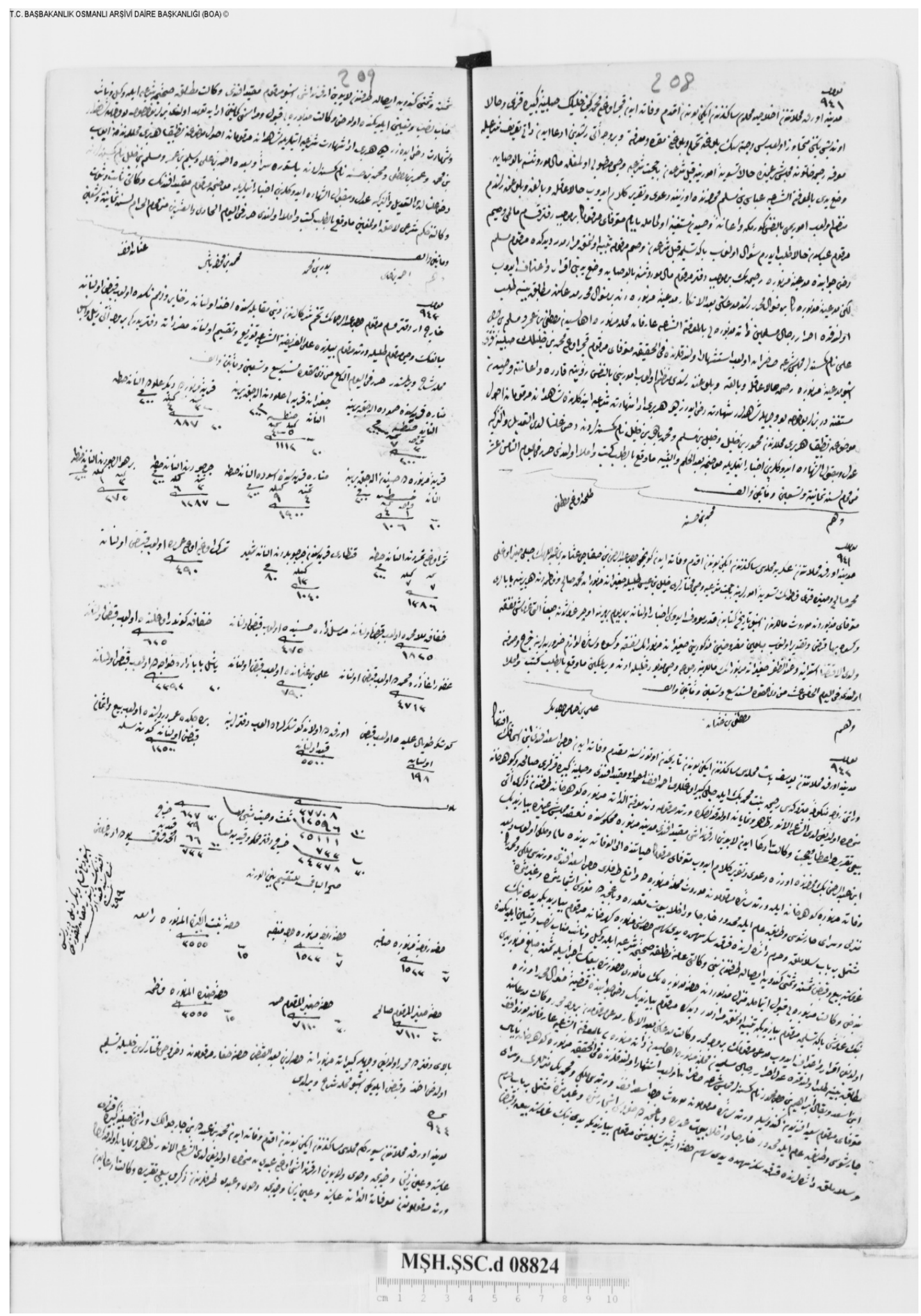

BOA, MŞH.ŞSC.d., Urfa Şer'iye Sicili, Sicil No: 208. 